\title{
CORPORATE GOVERNANCE SEBAGAI PEMICU PENGUNGKAPAN INTELLECTUAL CAPITAL PADA PERUSAHAAN DI INDONESIA
}

\begin{abstract}
Intangible assets proxied by Intellectual Capital play an important role as the key to success and the trigger for the creation of company's value. The current trend is that companies have not yet focused on Intellectual Capital disclosure. With the implementation of Corporate Governance mechanism, it is expected to support the disclosure of IC, so as to add values to the company.

This study aims to analyze corporate governance mechanism as a trigger of Intellectual Capital disclosure to companies in Indonesia. The population of this study was companies included in the ranking of CG implementation conducted by The Indonesian Institute for Corporate Governance (IICG) in 2011, 2012 and 2013. The sample was taken by purposive sampling method.

This study used secondary data, i.e. company's annual report where then the data were processed with simple linear regression. The result showed that corporate governance did not have any influence to intellectual capital disclosure.
\end{abstract}

Keyword: Intellectual Capital, Corporate Governance, Disclosure, Intangible Asset, Indonesia Companies

\section{PENDAHULUAN}

Intellectual Capital mewakili semua sumber daya (asset) tak berwujud yang tersedia bagi sebuah perusahaan dan memberi keuntungan relatif, serta pengkombinasiannya dengan sumber daya perusahaan yang lainnya akan menghasilkan keuntungan dimasa mendatang. Di masa sekarang IC mengambil peranan yang cukup signifikan bagi manajemen, yaitu sebagai pencipta nilai (value creation) sebuah perusahaan. Inovasi-inovasi kreatif yang dilakukan menjadi sebuah keunggulan kompetitif, inovasi kreatif yang ada tersebut dihasilkan oleh IC. Kecenderungan yang ada sekarang adalah perusahaan belum fokus pada pengungkapan Intellectual Capital.

Sebagai salah satu pencipta nilai bagi sebuah perusahaan. IC diharapkan dapat menambah dan memaksimalkan nilai perusahaan dimata investor. Ditambahkan pula bahwa, pengungkapan IC pada annual report membantu pasar modal menyediakan kapitalisasi pasar yang lebih akurat dari perusahaan (Guthrie et al., 1999 dalam Abeysekera, 2008). Dengan penerapan mekanisme Corporate Governance diharapkan dapat mendukung pengungkapan IC, sehingga dapat menambah nilai perusahaan.

Berbagai penelitian mengenai pengaruh mekanisme corporate covernance terhadap pengungkapan Intellectual Capital menemukan hasil yang beragam. Cerbioni dan Parboneti (2007) menemukan bahwa secara kuantitas semua variabel yang terdiri dari ukuran dewan, keindependensian komisaris independen, struktur dewan dan dualitas CEO mempunyai pengaruh positif pada pengungkapan IC, disisi lain secara kualitas hanya keindependensian komisaris independen yang mempunyai pengaruh positif. Hasil yang berbeda ditemukan oleh Woodcock dan Whiting (2009), yang mengemukakan bahwa hanya variabel Jenis auditor saja yang 
mempunyai pengaruh positif.

Li et al, (2007) menyatakan, ukuran komite audit dan kepemilikan saham direktur mempunyai hubungan positif dengan pengungkapan IC sedangkan proporsi dewan komisaris dan konsentrasi kepemilikan mempunyai pengaruh negatif terhadap pengungkapan IC, dan dari variabel control yang digunakannya yaitu size dan jenis industri, keduanya berpengaruh terhadap pengungkapan IC, hal tersebut berbeda dengan penelitian yang dilakukan oleh White et al., (2007) yang menemukan bahwa diantara mekanisme corporate governance yang ada hanya proporsi komisaris independen yang berpengaruh terhadap pengungkapan IC, juga variabel independen lain seperti umur perusahaan, ukuran perusahaan dan tingkat leverage.

Beragamnya mekanisme CG yang mempengaruhi pengungkapan IC memberikan hasil yang belum konsisten, sehingga menarik untuk dilakukan penelitian sejenis. Penelitian ini penting dilakukan mengingat : 1). hasil penelitian yang ada belum dapat digeneralisasi, 2) Penerapan corporate governance antara negara berkembang (Abeysekera, 2009) dan negara maju (Cerbioni dan Parbonetti, 2007) mempunyai sistem berbeda, 3) Belum adanya standar pengungkapan Intellectual Capital.

Perbedaan penelitian ini dengan penelitian sebelumnya adalah pada : Satu, mekanisme CG yang digunakan tidak berupa variabel secara parsial tetapi menggunakan skor pengungkapan CG, terdiri dari 51 item pengungkapan yang terbagi ke dalam 8 kategori (Jiang et al, 2008; Brown dan Caylor,2006) 2; Dua, pengungkapan IC diproksi dengan model VAIC ${ }^{\mathrm{TM}}$; Tiga, Populasi dalam penelitian ini adalah perusahaanperusahaan yang masuk dalam pemeringkatan penerapan CG yang dilakukan oleh The Indonesian Institute for Corporate Governance (IICG) tahun 2011, 2012 dan 2013. Hal ini didasarkan pada pada pertimbangan bahwa perusahaan yang menerapkan CG dengan baik akan memberikan informasi yang lebih banyak.

\section{LANDASAN TEORI DAN PENGEMBANGAN HIPOTESIS}

\section{Teori Keagenan}

Teori keagenan (agency theory) erat hubunganya dengan corporate governance. Teori ini adalah dasar yang digunakan perusahaan memahami corporate governance (Hikmah et al., 2011). Teori keagenan membahas hubungan antara prinsipal (pemilik dan pemegang saham) dan agen (managemen). Jensen dan Meckling (1976) (dikutip Hikmah et al., 2011) menyatakan bahwa bahwa hubungan keagenan muncul ketika satu atau lebih individu (principal) memperkerjakan individu lain (agent) untuk memberikan suatu jasa dan kemudian mendelegasikan kekuasaan kepada agen untuk membuat suatu keputusan atas nama principal tersebut. Hal ini menjadi dasar perlunya managemen melakukan pelaporan dan pengungkapan merngenai perusahaan kepada pemilik sebagai wujud akuntabilitas manajemen terhadap pemilik.

Menurut Eisenhardt (dikutip Warsono et al., 2009), teori keagenan menggunakan 3 asumsi sifat manusia, yaitu:

1. Manusia pada umumnya mementingkan diri sendiri (self interest).

2. Manusia memiliki daya pikir terbatas mengenai persepsi masa mendatang (bounded rationality).

3. Manusia selalu menghindari resiko (risk averse). 
Dari teori Eisenhardt di atas, dapat disimpulkan bahwa asumsi yang utama dari teori keagenan bahwa tujuan principal dan tujuan agen yang berbeda dapat memunculkan konflik karena manajer perusahaan cenderung untuk mengejar tujuan pribadinya sendiri, misalnya berusaha untuk memperoleh bonus setinggi mungkin. Manajer cenderung untuk menunjukkan "egoisme" (perilaku yang mengarahkan mereka untuk memaksimalkan kepentingan diri mereka sendiri). Hal ini dapat mengakibatkan kecenderungan manajer untuk memfokuskan pada proyek dan investasi perusahaan yang menghasilkan laba yang tinggi dalam jangka pendek daripada memaksimalkan kesejahteraan pemegang saham melalui investasi di proyek-proyek yang menguntungkan dalam jangka panjang.

Terdapat sejumlah cara untuk menyelaraskan kepentingan pemegang saham (principal) dengan manajer (agent), salah satunya adalah dengan melakukan penerapan dan pengungkapan terkait isu CG. Dengan penerapan CG, diharapkan perusahaan (agent) dapat melaksanakan tanggung jawab terhadap semua pemangku kepentingan, termasuk pemegang saham sebagai principal (Warsono et al., 2009) sehingga konflik kepentingan antara agent dan principal dapat diminimalkan. Dalam menanggulangi masalah asimetri ini, diharapkan perusahaan dapat mengungkapkan dan mengimplementasikan CG dengan baik dan benar demi membuktikan komitmen perusahaan terhadap pemangku kepentingan sehingga dapat mengurangi resiko yang terburuk, yaitu kebangkrutan perusahaan.

\section{Corporate Governance}

Menurut Anyta dan Mutmainah (2011) Corporate Governance merupakan suatu cara untuk menjamin bahwa manajemen bertindak yang terbaik untuk kepentingan stakeholders. Pelaksanaan good corporate governance menuntut adanya perlindungan yang kuat terhadap hak-hak pemegang saham, terutama pemegang saham minoritas. Prinsip-prinsip atau pedoman pelaksanaan Corporate Governance menunjukkan adanya perlindungan tersebut, tidak hanya kepada pemegang saham, tetapi meliputi seluruh pihak yang terlibat dalam perusahaan termasuk masyarakat.

Di Indonesia sendiri, Forum for Corporate Governance in Indonesia (FCGI) (dikutip Natalia, 2012) mendefinisikan CG sebagai seperangkat peraturan yang menetapkan hubungan antara pemangku kepentingan, pengurus, pihak kreditur, pemerintah, karyawan, serta para pemegang kepentingan internal dan eksternal lainnya. Dari definisi-definisi yang dipaparkan oleh para ahli di atas dapat disimpulkan bahwa CG adalah seperangkat aturan yang dijalankan oleh pihak-pihak yang berkepentingan untuk memastikan bahwa aktivitas dan tujuan perusahaan adalah untuk memenuhi kepentingan-kepentingan dan menyejahterakan para pemangku kepentingan, tidak semata-mata mencapai tujuan perusahaan itu sendiri.

Dalam pencapaiantujuanjangka panjang, selain merumuskan definisiCG, entitasCGjugamengembangkan asas-asas atau prinsip-prinsip CG (Natalia dan Zulaikha, 2012). OECD (Organization for Economic Co-operation and Development) mengembangkan lima prinsip Good Corporate Governance, yaitu:

1. Perlindungan terhadap hak-hak pemegang saham.

2. Persamaan perlakuan terhadap seluruh pemegang saham termasuk pemegang saham asing dan minoritas. 
3. Peranan pemangku kepentingan yang terkait dengan perusahaan.

4. Keterbukaan dan transparansi.

Sedangkan di Indonesia, Komite Nasional Kebijakan Governance (KNKG) dalam pedoman Umum Good Corporate Governance (GCG) tahun 2006 menetapkan lima prinsip CG yaitu sebagai berikut:

Transparansi (Transparency). Untuk menjaga obyektivitas dalam menjalankan bisnis, perusahaan harus menyediakan informasi yang material dan relevan dengan cara yang mudah diakses dan dipahami oleh pemangku kepentingan. Perusahaan harus mengambil inisiatif untuk mengungkapkan tidak hanya masalah yang disyaratkan oleh peraturan perundang-undangan, tetapi juga hal yang penting untuk pengambilan keputusan oleh pemegang saham, kreditur dan pemangku kepentingan lainnya.

Akuntabilitas (Accountability). Perusahaan harus dapat mempertanggungjawabkan kinerjanya secara transparan dan wajar. Untuk itu perusahaan harus dikelola secara benar, terukur dan sesuai dengan kepentingan perusahaan dengan tetap memperhitungkan kepentingan pemegang saham dan pemangku kepentingan lain. Akuntabilitas merupakan prasyarat yang diperlukan untuk mencapai kinerja yang berkesinambungan.

Responsibilitas (Responsibility). Perusahaan harus mematuhi peraturan perundang-undangan serta melaksanakan tanggung jawab terhadap masyarakat dan lingkungan sehingga dapat terpelihara kesinambungan usaha dalam jangka panjang dan mendapat pengakuan sebagai good corporate citizen. Independensi (Independency). Untuk melancarkan pelaksanaan asas GCG, perusahaan harus dikelola secara independen sehingga masing-masing organ perusahaan tidak saling mendominasi dan tidak dapat diintervensi oleh pihak lain. Kewajaran dan Kesetaraan (Fairness). Dalam melaksanakan kegiatannya, perusahaan harus senantiasa memperhatikan kepentingan pemegang saham dan pemangku kepentingan lainnya berdasarkan asas kewajaran dan kesetaraan.

Partisipan merupakan organ perusahaan yang sangat berperan penting untuk menegakkan CG di perusahaan (Warsono et al., 2009). Dengan tugas dan tanggung jawabnya masing-masing, partisipan menentukan arah perkembangan dan kebijakan perusahaan. Dengan kata lain, baik atau buruknya CG tergantung pada apa yang dilaksanakan partisipan dan bagaimana partisipan berupaya untuk menjalankan fungsi tersebut sesuai prinsip-prinsip CG yang dianut (Warsono et al., 2009). Terdapat lima jenis partisipan CG yang meliputi:

1. Boards of Directors (BoD)

2. Chief Executive Officers (CEO)

3. Board of Commissioners (BoC) :

a). One Tier System (Anglo Saxon)

b). Two Tier System (Kontinental Eropa)

4. Auditor : Auditor Internal dan Auditor Eksternal

5. Stakeholders (pemangku kepentingan):

a) Pemegang Saham

b IKaryawan 

c) Pelanggan.
d) Komunitas / Masyarakat sosial.
e) Kreditor
f) Pemerintah

Laporan tahunan berisi pengungkapan informasi yang dapat membantu stakeholders dalam pengambilan keputusan. Informasi yang diungkapkan tidak hanya berupa informasi keuangan saja, tetapi juga laporan non keuangan. Selain digunakan sebagai dasar pengambilan keputusan, pengungkapan dalam laporan tahunan juga digunakan sebagai bentuk pertanggungjawaban dan akuntabilitas manajemen atas kinerja pengelolaan perusahaan kepada para investor sebagai pemilik (Natalia dan Zulaikha, 2012).

\section{Intellectual Capital}

Dalam Rupidara (2008) terdapat beberapa definisi mengenai Modal Intelektual (Capital Intellectual/IC), antara lain oleh Lonnqvist dan Mettanen yang mendefinisikan Capital Intellectual sebagai sebuah konsep, modal intelektual merujuk pada modal-modal non fisik atau yang tidak berwujud (intangible assets) atau tidak kasat mata (invisible). la terkait dengan pengetahuan dan pengalaman manusia serta teknologi yang digunakan. Modal intelektual memiliki potensi memajukan organisasi dan masyarakat. Dan secara ringkas Smedlund dan Poyhonen; 2005 (dalam Rupidara, 2008) mewacanakan modal intelektual sebagai kapabilitas organisasi untuk menciptakan, melakukan transfer, dan mengimplementasikan pengetahuan, seperti yang dinyatakan oleh Williams (2001) dalam Purnomosidhi (2006), modal intelektual adalah informasi dan pengetahuan yang diaplikasikan dalam pekerjaan untuk menciptakan nilai.

Beberapa kerangka konseptual dapat digunakan untuk mengelompokkan dan melaporkan IC. Sveiby, 1997 dalam Cerbioni dan Parbonetti (2007) menawarkan sebuah kerangka yang membagi IC ke dalam tiga kelompok, yaitu:

Human Capital (modal manusia). Human capital merupakan lifeblood dalam modal intelektual. Disinilah sumber innovation dan improvement, tetapi merupakan komponen yang sulit untuk diukur. Human capital juga merupakan tempat bersumbernya pengetahuan yang sangat berguna, keterampilan, dan kompetensi dalam suatu organisasi atau perusahaan. Human capital mencerminkan kemampuan kolektif perusahaan untuk menghasilkan solusi terbaik berdasarkan pengetahuan yang dimiliki oleh orang-orang yang ada dalam perusahaan tersebut. Human capital akan meningkat jika perusahaan mampu menggunakan pengetahuan yang dimiliki oleh karyawannya, seperti ; intelektual, keahlian, kreativitas, cara kerja.

Structural Capital atau Organizational Capital (modal organisasi). Structural capital merupakan kemampuan organisasi atau perusahaan dalam memenuhi proses rutinitas perusahaan dan strukturnya yang mendukung usaha karyawan untuk menghasilkan kinerja intelektual yang optimal serta kinerja bisnis secara keseluruhan, misalnya: sistem operasional perusahaan, proses manufakturing, budaya organisasi, filosofi manajemen dan semua bentuk intellectual property yang dimiliki perusahaan. Seorang individu dapat memiliki tingkat intelektualitas yang tinggi, tetapi jika organisasi memiliki sistem dan prosedur yang buruk maka intellectual 
capital tidak dapat mencapai kinerja secara optimal dan potensi yang ada tidak dapat dimanfaatkan secara maksimal.

Relational Capital atau Costumer Capital (modal pelanggan). Elemen ini merupakan komponen modal intelektual yang memberikan nilai secara nyata. Relational capital merupakan hubungan yang harmonis/ association network yang dimiliki oleh perusahaan dengan para mitranya, baik yang berasal dari para pemasok yang andal dan berkualitas, berasal dari pelanggan yang loyal dan merasa puas akan pelayanan perusahaan yang bersangkutan, berasal dari hubungan perusahaan dengan pemerintah maupun dengan masyarakat sekitar, seluruh relasi eksternal dengan konsumen, seperti; suppliers, partners, networks, dan regulators.

\section{Pengembangan Hipotesis}

Penelitian yang ada sebelumnya, mengenai pengaruh mekanisme corporate governance terhadap pengungkapan Intellectual Capital menggunakan proksi yang hampir sama. Mekanisme yang digunakan meliputi ukuran dan komposisi dewan komisaris, keberadaan dan komposisi komite audit serta struktur kepemilikan yang diperluas. Banyak kritik ditujukan pada penelitian yang sudah ada (Jiang, 2008), karena CG memiliki banyak segi permasalahan dan komplek. Penelitian ini mencoba mengisi kesenjangan yang ada dengan menggunakan skor governance yang diformulasikan oleh Jiang et al, 2008; Brown dan Caylor,2006.

Beberapa penelitian terdahulu (Cerbioni dan Parbonetti, 2007; Abeysekera, 2009; dan Li et al, 2007), data pengungkapan IC diperoleh dengan menggunakan content analysis mengacu pada komponen IC milik Sveiby (1997 dalam Cerbioni dan parbonetti, 2007) dengan beberapa modifikasi. Metode content analysis bersifat subjektif sehingga data yang dihasilkan kurang reliable. Untuk mendapatkan data yang lebih reliable mengenai pengungkapan IC, maka dalam penelitian ini menggunakan metode VAIC ${ }^{\mathrm{TM}}$ (Pulic 1999 dalam Widarjo, 2011). Berdasarkan penjelasan diatas, maka dapat dirumuskan hipotesis sebagai berikut :

\section{$\mathbf{H}_{1}$ : Corporate Governance berpengaruh pada pengungkapan Intellectual Capital perusahaan di Indonesia}

\section{METODE PENELITIAN}

\section{Populasi dan Sampel}

Populasi dalam penelitian ini adalah perusahaan-perusahaan yang masuk dalam pemeringkatan penerapan CG yang dilakukan oleh The Indonesian Institute for Corporate Governance (IICG) tahun 2011, 2012 dan 2013. Data diperoleh dari dan Annual Report yang telah dipublikasikan pada website www.idx.co.id. Sampel dipilih dengan metode purposive sampling dengan syarat memenuhi kriteria sebagai berikut: (1). Perusahaan sampel mempunyai tahun buku yang berakhir 31 Desember dan mempublikasikan laporan tahunan (Annual Report) lengkap selama tahun pengamatan. (2). Perusahaan sampel memiliki data yang lengkap terkait dengan variabel - variabel yang digunakan dalam penelitian. Berdasarkan kriteria yang ada diperoleh sample 63 perusahaan. 


\section{Definisi Oprasional dan Pengukuran Variabel}

Pengungkapan Intelectual Capital

Variabel dependen dalam penelitian ini adalah pengungkapan IC, data diperoleh menggunakan model VAIC $^{\text {TM }}$. Variabel Dependen (Pulic, 2000 dalam Widarjo 2011) :

$$
\begin{array}{ll}
\text { VAIC }^{\text {TM }} & =V A C A+V A H U+S T V A \\
V A & =O P+E C+D+A
\end{array}
$$

Dimana :

OP = Laba Bersih (Operating Profit)

$\mathrm{EC}=$ Beban Karyawan (Employee Costs)

D = Depresiasi (Depreciation)

A $\quad=$ Amortisasi (Amorisation)

a). VACA merupakan indikator value added yang diciptakan oleh satu unit physical capital, dihitung dengan : $V A C A=\underline{V A}$

CE

Dimana: CE ; dana yang tersedia (ekuitas, laba bersih)

b). VAHU merupakan indikator berapa banyak value added dapat dihasilkan dengan dana yang dikeluarkan untuk tenaga kerja

$$
\text { VAHU }=\frac{V A}{H C}
$$

Dimana: HC ; Human Capital , beban karyawan

c). STVA mengukur jumlah SC yang dibutuhkan untuk menghasilkan 1 rupiah dari VA dan merupakan indikasi bagaimana keberhasilan SC dalam penciptaan nilai.

$$
\text { STVA }=\frac{\text { SC }}{\text { VA }}=\frac{\text { VA }-H C}{V A}
$$

\section{Corporate Governance}

Variabel dependen dalam penelitian ini adalah luas pengungkapan corporate governance yang terdapat pada laporan tahunan perusahaan yang diukur dengan indeks pengungkapan corporate governance sebagai standar untuk mengukur tingkat pengungkapan corporate governance pada perusahaan perbankan yang terdaftar di Bursa Efek Indonesia. Indeks pengungkapan corporate overnance pada laporan tahunan perusahaan dapat dihitung menggunakan rumus sebagai berikut (Bhuiyan dan Biswas, 2007): 


$$
\text { IPCG }=\frac{\text { Total item yang diungkap perusahaan }}{\text { Skor Maksimum yang seharusnya diungkapkan perusahaan }} \times 100 \%
$$

Skor corporate governance (51 item yang terbagi menjadi 8 kategori): (Brown and Caylor, 2006; Jiang et, al 2008)

\section{Teknik Analisis}

\section{Analisis Statistik Deskriptif}

Analisis statistik deskriptif memberikan informasi umum mengenai data yang akan diuji dalam penelitian ini. Alat analisis yang digunakan adalah mean, nilai maksimum, nilai minimum, dan standar deviasi untuk mendeskripsikan variabel penelitian.

\section{Analisis Regresi Sederhana}

Analisis regresi linier sederhana adalah hubungan secara linear antara satu variabel independen $(X)$ dengan variabel dependen (Y). Analisis ini untuk mengetahui arah hubungan antara variabel independen dengan variabel dependen apakah positif atau negatif dan untuk memprediksi nilai dari variabel dependen apabila nilai variabel independen mengalami kenaikan atau penurunan.. Data yang digunakan biasanya berskala interval atau rasio. Rumus regresi linear sederhana sebagi berikut:

$$
\operatorname{VAIC}^{\mathrm{TM}}=\mathrm{a}+\text { bIPCG }
$$

Keterangan:

VAIC $^{\text {TM }}=$ Pengungkapan Intellectual Capital

IPCG = Indeks Pengungkapan CG

\section{Pengujian Hipotesis}

Uji statistik menunjukkan seberapa jauh pengaruh satu variabel independen secara individual dalam menerangkan variasi variabel independen (Ghozali, 2011). Pengujian dilakukan dengan mengukur nilai probabilitas siginifikansi. Jika nilai probabilitas signifikansi $\leq 0.05$ maka hipotesis tidak dapat ditolak. Ini berarti secara individual variabel independen mempunyai pengaruh signifikan terhadap variabel dependen. Sebaliknya jika nilai probabilitas signifikansi $\geq 0.05$ maka hipotesis ditolak. Ini berarti secara individual variabel independen tidak mempunyai pengaruh signifikan terhadap variabel dependen.

\section{HASIL DAN PEMBAHASAN}

\section{Hasil}

Jumlah populasi perusahaan yang masuk dalam pemeringkatan penerapan CG, yang dilakukan oleh The Indonesian Institute for Corporate Governance (IICG), selama tahun 2011, 2012 dan 2013 sebanyak 101 perusahaan. Dari populasi yang ada sebanyak 63 perusahaan diambil sebagai sampel dengan metode purposive sampling. Sebanyak 38 perusahaan sampel tidak memenuhi kriteria, dikarenakan tidak memiliki data lengkap 
terkait dengan variabel penelitian. Peroleh data pengungkapan IC dilakukan dengan menggunakan model $\mathrm{VAIC}^{\mathrm{TM}}$. Sedangkan data variable dependen diperoleh dengan indeks pengungkapan corporate governance.

\section{Hasil Statistik Deskriptif}

Pengungkapan IC dalam penelitian ini diukur dengan model VAIC ${ }^{\text {TM }}$. Dari pengungkapan IC yang ada dapat dilihat bahwa untuk pengungkapan IC mempunyai nilai standar deviasi yang lebih besar dari nilai rata-rata, hal ini menunjukkan bahwa pengungkapan Intellectual Capital (IC) dari masing-masing perusahaan sampel memiliki perbedaan besaran yang relatif kecil antar masing-masing perusahaan sampel (Tabel.2)

Pengungkapan corporate governance dalam penelitian ini diukur dengan indek pengungkapan corporate governance. Dari pengungkapan CG yang ada dapat dilihat bahwa pengungkapan CG mempunyai nilai standar deviasi yang lebih kecil daripada rata-rata, hal ini menunjukkan bahwa pengungkapan Corporate Governance (CG) dari masing-masing perusahaan sampel memiliki besaran yang hampir sama antar masingmasing perusahaan sampel.

Dari masing-masing item CG (8 item pengungkapan) dapat disimpulkan bahwa perusahaan sampel menerapkan komponen CG dengan baik, serta mengungkapkannya dalam annual report. Sebagian besar item pengungkapan mempunyai tingkat pengungkapan diatas 0,5 (Tabel.3)

\section{Hasil Analisis Regresi}

Berdasarkan hasil output SPSS yang ada diperoleh persamaan fungsi regresi linier sederhana sebagai berikut :

$$
\operatorname{VAIC}^{\mathrm{TM}}=\mathrm{a}+0,333 \mathrm{IPCG}
$$

Untuk nilai Sig didapatkan hasil 0,333 yang berarti lebih besar daripada kriteria signifikan (0,05). Dengan demikian model persamaan regresi dengan data penelitian yang ada adalah tidak signifikan. Hal ini berarti bahwa model regresi linier tidak memenuhi kriteria linieritas.

Hasil analisis menunjukkan bahwa nilai korelasi adalah hanya sebesar 0,124. Nilai ini dapat diinterpretasikan bahwa hubungan kedua variabel penelitian termasuk dalam kategori lemah. Melalui tabel yang ada juga diperoleh nilai $\mathrm{R}$ Square atau koefisien determinasi (KD) yang menunjukkan seberapa bagus model regresi yang dibentuk oleh interaksi variabel bebas dan variabel terikat. Nilai KD yang diperoleh adalah 1,5\% yang dapat ditafsirkan bahwa variabel bebas $X$ hanya memiliki pengaruh kontribusi sebesar 1,5\% terhadap variabel Y dan 98,5\% lainnya dipengaruhi oleh faktor-faktor lain diluar variabel $\mathrm{X}$.

\section{Pengujian Hipotesis}

Berdasarkan hasil pengujian hipotesis, diperoleh bukti bahwa corporate governance tidak berpengaruh terhadap pengungkapan IC perusahaan di Indonesia. Hal ini ditunjukkan dengan probabilitas signifikansi pada variabel IPCG sebesar 0,333. Dengan nilai signifikansi lebih besar daripada 0,05, maka dapat disimpulkan bahwa hitpotesis ditolak (Tabel.4) 


\section{Pembahasan}

Berdasarkan pada pengujian empiris yang telah dilakukan terhadap hipotesis dalam penelitian, hasilnya menunjukkan corporate governance tidak berpengaruh terhadap pengungkapan IC. Hasil penelitian ini tidak sejalan dengan Cerbioni dan Parbonetti (2007), Abeysekera (2009), Abeysekera (2009) dan Gan et.al (2008) yang menyatakan bahwa Corporate Governance (Dewan Komisaris, Komisaris Independen dan Komite Audit) berpengaruh terhadap pengungkapan Intellectual Capital.

Penelitian ini menemukan hasilanalisis yang bertentangan denganteori dasarnya, yang mengemukakan bahwa penerapan CG mengharuskan perusahaan melakukan berbagai jenis pengungkapan sebagai bentuk transparansi. Pengungkapan yang dilakukan meliputi pengungkapan wajib dan sukarela, termasuk adanya pengungkapan tentang IC.

Perusahaan sampel yang ada, meskipun masuk dalam pemeringkatan penerapan CG yang dilakukan oleh The Indonesian Institute for Corporate Governance (IICG), ternyata belum bisa menjadi pemicu adanya pengungkapan IC. Di Indonesia, penerapan CG sudah mengacu pada aturan yang berlaku, begitu juga dengan pengungkapannya. Namun demikian, organ-organ utama pelaksanaan CG seperti; Dewan Komisaris, Komisaris Independen dan Komite Audit dalam pembentukanya tidak sesuai dengan tujuan semula. Anggota dewan komisaris yang ada, tidak jarang diangkat atau berasal dari pihak yang kurang berkompeten. Mereka di tunjuk sebagai anggota dewan komisaris sebagai bentuk penghargaan, karena adanya hubungan kekerabatan atau kenalan dekat. Dewan komisaris yang ada menjadi kurang begitu berperan dalam fungsi pengawasan dan monitoring, dikarenakan tidak adanya kompetensi pada dewan komisaris, sehingga komisaris independen yang merupakan hasil penunjukan dewan komisaris, juga menjadi tidak berkompeten dalam menjalankan fungsinya.

\section{KESIMPULAN, KETERBATASAN DAN SARAN}

\section{Kesimpulan}

Di masa sekarang IC mengambil peranan yang cukup signifikan bagi manajemen, yaitu sebagai pencipta nilai (value creation) sebuah perusahaan. Sebagai salah satu pencipta nilai bagi sebuah perusahaan. IC diharapkan dapat menambah dan memaksimalkan nilai perusahaan dimata investor. Dengan penerapan mekanisme Corporate Governance diharapkan dapat mendukung pengungkapan IC, sehingga dapat menambah nilai perusahaan.

Berdasarkan pada pengujian empiris yang telah dilakukan terhadap hipotesis dalam penelitian, hasilnya menunjukkan corporate governance tidak berpengaruh terhadap pengungkapan IC. Hasil penelitian ini tidak sejalan dengan Cerbioni dan Parbonetti (2007), Abeysekera (2009), Abeysekera (2009) dan Gan et.al (2008) yang menyatakan bahwa Corporate Governance (Dewan Komisaris, Komisaris Independen dan Komite Audit) berpengaruh terhadap pengungkapan Intellectual Capital.

Perusahaan sampel yang ada, meskipun masuk dalam pemeringkatan penerapan CG yang dilakukan oleh The Indonesian Institute for Corporate Governance (IICG), ternyata belum bisa menjadi pemicu adanya pengungkapan IC. Di Indonesia, penerapan CG sudah mengacu pada aturan yang berlaku, begitu juga dengan pengungkapannya. Namun demikian, organ-organ utama pelaksanaan CG seperti; Dewan Komisaris, 
Komisaris Independen dan Komite Audit dalam pembentukanya tidak sesuai dengan tujuan semula. Anggota dewan komisaris yang ada, tidak jarang diangkat atau berasal dari pihak yang kurang berkompeten.

\section{Keterbatasan}

Penelitian ini tidak mampu membuktikan hipotesis penelitian ini. Oleh karena itu, penelitian mendatang banyak hal yang bias dilakukan.

\section{Saran}

Untuk penelitian mendatang, dimasukkan variable indpenden lainnya yang terkait dengan pengungkapan IC seperti : ukuran perusahaan. Sedangkan variable dependen yang berupa pengungkapan CG belum sesuai di terapkan di Indonesia, bisa di eksplorasi dengan karekteristik corporate governance seperti : jumlah pertemuan, tingkat pendidikan dst. 


\section{DAFTAR PUSTAKA}

Abeysekera, Indra. (2008). "Intellectual Capital disclosure trends: Singapore and Sri Lanka". Journal of Intellectual Capital Vol. 9 No. 4, pp. 723-737, Emerald Group Publishing Limited 1469-1930

- (2009).“The Role of Corporate Governance Disclosure of Kenyan Listed Firms”.Diaksestanggal 27 Februari 2010, dariwww.business.uts.edu.au/accounting/seminars/spr09aug10abeysekera.pdf

Anyta dan Siti Mutmainah. 2011. "Analisis Pengaruh Mekanisme Corporate Governance Terhadap Voluntary

Corporate Governance Disclosure", Undergraduate thesis (unpublished), Universitas Diponegoro

Bhuiyan, Md Hamid Ullah and P.K. Biswas. 2007. "Corporate Governance and Reporting: An Empirical Study of The Listed Companies in Bangladesh", Journal of Business Studies

Brown, Lawrence. D dan Marcus L.Caylor.(2006). "Corporate Governance and Firm Valuation".Journal of Accounting and Public Policy 25 (2006), 409 - 434, diaksesdariwww.sciencedirect.com pada 27 April 2013

Cerbioni, Fabrizio dan Antonio Parbonetti. (2007). "Exploring the Effects of Corporate Governance on Intellectual Capital Disclosure: An Analysis of European Biotechnology Companies". European Accounting Review, Volume 16, Issue 4 December 2007 , pages 791 - 826

Gan, Kin, Zakiah Saleh, dan Masoud Abessi (2008), " Corporate Governance, Ownership Structures and Intellectual Capital Disclosures: Malaysian Evidence", diakses tanggal 27 Juni 2010 dari www.google.com

Ghozali, Imam. 2011. Aplikasi Analisis Multivariate dengan Program SPSS. Semarang: Badan Penerbit Universitas Diponegoro

Hikmah Noor, Chairina, dan Desilarina Rahmayanti. 2011."Faktor-Faktoryang Mempengaruhi Luas Pengungkapan Corporate Governance Pada Perusahaan Perbankan yang Terdaftar di Bursa Efek Indonesia ", Simposium Nasional Akuntansi XIV

Jiang, Wei, Picheng Lee dan Asokan Anandarajan (2008), "The Association Between Corporate Governance and Earning Quality : Further Evidence using The Gov-Score". Journal of Advances in Accounting Incorporating Advances International Accounting 24 (2008), 191 - 201, diaksesdariwww.elsevier.compada 11 Agustus 2010

Li, Jing, Richard Pike, dan Roszaini Haniffa (2007). "Intellectual Capital Disclosure in Knowledge Rich Firms: The Impact of Market and Corporate Governance Factors", Working paper series, Diaksestanggal 27 Juni 2010 dariwww.britannica.com

Natalia Petri dan Zulaikha. 2012. "Analisis Faktor-Faktor yang Mempengaruhi Pengungkapan Corporate Governance pada Laporan Tahunan", Journal of Accounting

Natalia Petri. 2012. "Analisis Faktor-Faktor yang Mempengaruhi Pengungkapan Corporate Governance pada Laporan Tahunan", Skripsi Program Sarjana Jurusan Akuntansi Fakultas Ekonomika dan Bisnis, Universitas Diponegoro

Purnomosidhi, Bambang. (2006). "Praktik Pengungkapan Modal Intelektual pada Perusahaan Publik di BEJ", Jurnal Riset Akuntansi Indonesia Vol.9, No.1, Januari 2006 Hal 1-20

Rupidara, Neil, (2008). "Modal Intelektual dan Strategi Pengembangan Organisasi dan Sumber Daya Manusia". 
Dipresentasikan pada Forum Diskusi PSKTI Universitas Kristen Satya Wacana tanggal 21 Februari 2008

Warsono, Sony, Fitri Amalia, dan Dian Kartika Rahajeng. 2009. "Corporate Governance Concept and Model". Yogyakarta: CGCG FEB UGM

White, Gregory, Alina Lee, dan Greg Tower. (2007). “Drivers of Voluntary Intellectual Capital Disclosure inListed Biotechnology Companies".Journal of Intellectual Capital 8 (3) : 517-537 Emerald Group Publishing Limited 1469-1930

Widarjo, Wahyu (2011). "Pengaruh Modal Intelektual dan Pengungkapan Modal IntelektualpadaNilai Perusahaan". Simposium Nasional Akuntansi XIV, Aceh, 21 - 22 Juli 2011

Woodcock, James dan Whiting, Rosalind H. (2009)."Intellectual Capital Disclosures by Australian Companies". Paper accepted for presentation at the AFAANZ Conference, Adelaide, Australia, July 2009. Diaksestanggal 12 Juni 2010 dariwww.otago.ac.nz 


\section{LAMPIRAN}

Tabel l. Deskripsi SampelPenelitian

Keterangan Jumlah

Jumlah Populasi Perusahaan yang masuk peringkat IICG selama $\quad 101$

th. $2011-2013$

1. Perusahaan sampel mempunyai tahun buku yang berakhir 31 Desember dan mempublikasikan laporan tahunan (Annual Report) lengkap selarna tahun pengaratan.

2. Perusahaan sampel memiliki data yang lengkap terkait deng an variabel - variabel yang digunakan dalam pene litian.

Sampel data yang diolah

Tabel 2. Statistik Deskriptif

Descriptive Statistics

\begin{tabular}{|l|r|r|r|r|r|}
\hline & $\mathrm{N}$ & Minimum & Maximum & \multicolumn{1}{l|}{ Mean } & Std. Deviation \\
\hline IC & 63 & -16.10 & 110.54 & 12.0340 & 19.59551 \\
IPCG & 63 & .51 & .76 & .6527 & .06451 \\
Valid N (listwise) & 63 & & & & \\
\hline
\end{tabular}


Tabel 4. Pengaruh CG terhadap Pengungkapan Intellectual Capital

\section{Coefficients $^{\mathrm{a}}$}

\begin{tabular}{|c|c|c|c|c|c|c|}
\hline \multirow{2}{*}{ Model } & & \multicolumn{2}{|c|}{ Unstandardized Coefficients } & \multirow{2}{*}{$\begin{array}{c}\text { Standardized } \\
\text { Coefficients } \\
\text { Beta }\end{array}$} & \multirow[t]{2}{*}{$\mathrm{t}$} & \multirow{2}{*}{ Sig. } \\
\hline & & B & Std. Error & & & \\
\hline \multirow{2}{*}{1} & (Constant) & 36,605 & 25,312 & & 1,446 & 153 \\
\hline & IPCG & $-37,649$ & 38,598 &,- 124 &,- 975 & ,333 \\
\hline
\end{tabular}

a. Dependent Variable: VAICtm 